\title{
Fluid evolution in Tertiary magmatic-hydrothermal ore systems at the Rhodope metallogenic province, NE Greece. A review.
}

\author{
Vasilios Melfos ${ }^{1, *}$ and Panagiotis Voudouris ${ }^{2}$ \\ ${ }^{1}$ Aristotle University of Thessaloniki, Department of Mineralogy, Petrology and Economic Geology, Thessaloniki, 54124, Greece \\ (*corresponding author, email: melfosv@geo.auth.gr) \\ ${ }^{2}$ University of Athens, Department of Mineralogy-Petrology, Athens 15784, Greece \\ 157-167 3 Figs. 1 Tab. \\ doi: $10.4154 / \mathrm{gc} .2016 .12$
}

chess

Article history:

Received December 02, 2015

Revised and accepted January 01, 2016

Avaliable online February 29, 2016
Keywords: Fluid inclusions, metallogeny, Rhodope, intrusion related systems, porphyry systems, epithermal mineralizations

\begin{abstract}
Characterization of various fluid parameters in magmatic-hydrothermal ore mineralizations is potentially essential for interpretation of the conditions of formation and therefore for mineral exploration. Fluid inclusions can provide a useful and promising tool in the research of the ore forming processes in these systems. This review focuses on the nature, composition and origin of magmatic-hydrothermal ore forming fluids involved in the formation of representative Tertiary ore deposits at the Rhodope metallogenic province in NE Greece. These deposits are spatially related to Tertiary magmatism in NE Greece. Case studies are presented here and include an intrusion-hosted sheeted vein system (Kavala), a Au-rich carbonate replacement and quartz-vein mineralization (Asimotrypes), mineralized veins in Eptadendro-Rachi and Thasos island (Kapsalina and Panagia), porphyry Cu-Mo$\mathrm{Re}-\mathrm{Au}$ deposits in Pagoni Rachi and Maronia and epithermal Au-Ag mineralizations in Perama and Loutros. Hydrothermal fluids rich in $\mathrm{CO}_{2}$ together with elevated $\mathrm{Au}$ and $\mathrm{Te}$ content are common and occur at the Kavala intrusion hosted sheeted vein system, at the Asimotrypes Au-rich carbonate replacement mineralization and at the Panagia (Thasos) vein system. We classify all these ore mineralizations as intrusion-related gold systems (IRGS). Transport and precipitation of metals including Au and Te is favoured when $\mathrm{CO}_{2}$ is present. Precipitation of the ore mineralization takes place due to the immiscibility of the carbonic and the aqueous fluids which have a magmatic origin with the contribution of meteoric water. Cooling of magmatic hydrothermal fluids and dilution with meteoric water is a common cause for ore mineral formation in the vein mineralizations of Eptadendro/ Rachi and Kapsalina Thasos. At the Pagoni Rachi and Maronia porphyry deposits, boiling and the high proportion of the vapour phase are the most essential fluid processes which affected ore formation. The epithermal veins overprinting the Pagoni Rachi and the Maronia porphyry systems and the HS-IS epithermal system in Perama Hill and the IS epithermal mineralization in Loutros are characterized by low to moderate temperatures and low to moderate salinities. Cooling and dilution of the ore fluids are the main process for gold precipitation. We conclude that the different fluid parameters and microthermometric data indicate a variety of fluid origin conditions and sources which can affect the strategy for exploration and prospecting for gold, rare and critical metals.
\end{abstract}

\section{INTRODUCTION}

Large-scale magmatic-hydrothermal fluid circulation in the Earth's crust is derived from intermediate to felsic hydrous magmas mainly at convergent plate margins, providing endogenic heat and mass transfer for the formation of ore deposits including base, precious and rare metals (LEHMANN et al., 2000; BLUNDELL et al., 2005; SIMMONS \& BROWN, 2006; BORTNIKOV, 2006; HEINRICH, 2007). These systems involve large amounts of volatiles including magmatic, meteoric or metamorphic water in aqueous or vapour form, $\mathrm{CO}_{2}, \mathrm{NaCl}, \mathrm{KCl}, \mathrm{CaCl}_{2}, \mathrm{MgCl}_{2}, \mathrm{H}_{2} \mathrm{~S}, \pm \mathrm{CH}_{4}, \pm \mathrm{N}_{2}$, as well as metals which originate from the magmas or the leaching processes from the rocks penetrated by the fluids through fluidwall-rock interactions.

The detection of the various fluid characteristics is potentially important for interpretation of the formation of numer- ous ore deposit types and consequently for mineral exploration (BAKER \& LANG, 2001; WILKINSON, 2001; HEINRICH, 2005; CHANG et al., 2011; KESLER et al., 2013). For example boiling has been a valuable guide in gold and copper exploration in porphyry systems. It is useful therefore to know how the volatile phases originate, how they dissolve and transport metals, which is the role of temperature and pressure and under what conditions the metallic minerals are deposited.

A useful fluid parameter which can be achieved by the fluid inclusions study, especially in the systems associated with $\mathrm{Au}$ and other sidirophile elements enrichment, is the $\mathrm{CO}_{2}$ content, because there is a strong correlation between $\mathrm{CO}_{2}$ content and gold mineralization, such as in the deepseated intrusion-related systems (LOWENSTERN, 2001; BAKER 2002). In general, fluid inclusions with elevated homogenization temperatures and high salinities indicate magmatic productive fluids, while fluid inclusions with low ho- 
mogenization temperature and low salinity show incorporation of meteoric waters (WILKINSON, 2001; KESLER et al., 2013). It is evident that homogenization temperatures, fluid salinity, density and pressure, can be useful in the determination of the fluid sources, the physical and chemical processes of transport and deposition of metals and also to explain the chemical environments of ore deposition and the possible zonation patterns of some ore systems.

This review paper summarizes the nature, composition and origin of magmatic-hydrothermal ore forming fluids which were involved in the formation of representative Tertiary ore deposits at the Rhodope metallogenic province in NE Greece (Fig. 1) which are developed within or around magmatic intrusive or extrusive rocks. We explore the evolution of high temperature and high salinity magmatic brines or $\mathrm{CO}_{2}$-rich fluids, as well high temperature and low salinity magmatic vapours, to low temperature and low salinity meteoric fluids which were involved in the formation of these ore mineralizations.

This paper is partly motivated by microthermometric measurements of fluid inclusions which have been published in previous works of several researchers (VAVELIDIS et al., 1995; ELIOPOULOS, 2000; MELFOS et al., 2002; VAVELIDIS \& MELFOS, 2004; MELFOS et al., 2008, 2010; FORNADEL et al., 2011; ELIOPOULOS \& KILIAS, 2011; VOUDOURIS et al., 2011, 2013b) and include a reduced intrusionrelated system (Kavala), a Au-rich carbonate replacement mineralization (Asimotrypes), mineralized veins in Eptadendro-Rachi and Thasos island (Kapsalina and Panagia), porphyry $\mathrm{Cu} \pm \mathrm{Au} \pm$ Mo deposits in Pagoni Rachi and Maronia and epithermal mineralizations in Perama and Loutros (Fig. 1). The purpose of this work is to show that detailed exploration for the discovery of new ore deposits requires a thorough fluid inclusion study which will interpret fluid phase relations and evaluate fluid characteristics in view of the ore forming conditions.

\section{GEOLOGICAL SETTING OF TERTIARY ORE DEPOSITS}

Greece is traditionally a mining country with numerous ore deposits which include base $(\mathrm{Cr}, \mathrm{Ni}, \mathrm{Mn}, \mathrm{Al}, \mathrm{Fe}, \mathrm{Pb}, \mathrm{Zn}, \mathrm{Cu})$, precious ( $\mathrm{Au}, \mathrm{Ag}$, Platinum Group Elements-PGE), rare (Bi, Te, Mo, Re, Ti) \& critical (Mg, Sb, W, Co, Ga, Ge, In, REE) metals (MELFOS \& VOUDOURIS, 2012). Mining dates back to prehistoric times focusing initially on gold, copper and iron mineralizations. Later, in the Classical and Hellenistic times, ore exploitation became more intense especially for $\mathrm{Au}, \mathrm{Ag}$, $\mathrm{Cu}$ and $\mathrm{Fe}$. Famous ancient mining centres operated in Milos and Sifnos Islands (Aegean Sea), in Lavrion (Attica), in Chalkidiki, Palea Kavala, Pangeon Mt and Thasos Island (N. Greece), where a great number of underground galleries and metallurgical furnaces are still preserved (PERNICKA et al., 1981; GEORGAKOPOULOU et al., 2011). Several metals, such as $\mathrm{Ag}, \mathrm{Au}, \mathrm{Fe}, \mathrm{Cu}$, were also produced during the Byzantine and Ottoman periods (NERANTZIS, 2009). Since the beginning of the $20^{\text {th }}$ century a great number of ore deposits have been targeted for exploration and exploitation of $\mathrm{Cr}, \mathrm{Ni}, \mathrm{Al}$, $\mathrm{Mn}, \mathrm{Fe}, \mathrm{Pb}, \mathrm{Zn}, \mathrm{Cu}$, Au and Ag. Greece is the most important producing country in the EU for Ni-Fe (from laterites) and $\mathrm{Al}$

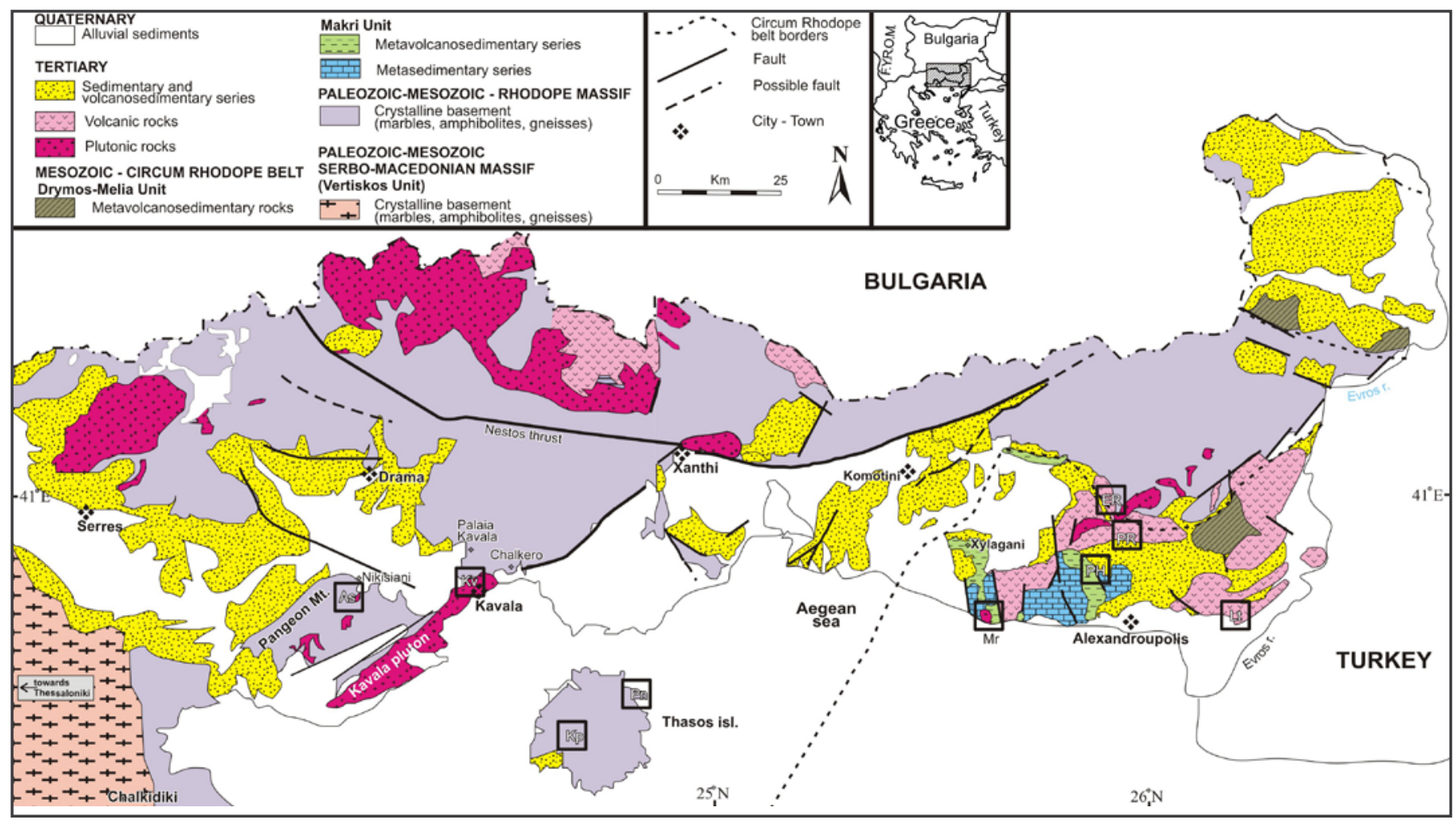

Figure 1. Simplified geological map of the Rhodope metallogenic province, NE Greece, showing the studied mineralizations. Kavala (Kv) intrusion-related system, Asimotrypes (As) Au-rich carbonate replacement mineralization, Eptadendro-Rachi (ER) mineralized veins, Kapsalina $(\mathrm{Kp})$ and Panagia (Pn) Cu-Bi-Ag \pm Te vein systems in Thasos island, Pagoni Rachi (PR) and Maronia (Mr) Cu-Mo-Re-Au porphyry deposits, Perama Hill (PH) and Loutros (Lt) epithermal mineralizations. 
(from bauxites). The production of $\mathrm{Mg}$ from magnesite is also significant (TSIRAMBIDES \& FILIPPIDIS, 2012).

The geological setting of the Hellenides, part of the AlpineHimalayan orogeny, comprises numerous geotectonic terrains, which resulted as a consequence of the complicated geodynamic events in the region of the Palaeotethys and Neotethys Oceans, including ocean rifting, spreading, subduction, collision, post-collision and extensive subduction and post-subduction magmatism (PE-PIPER \& PIPER, 2002). After closure of the Neotethys Ocean, syn-orogenic exhumation of HP-LT rocks occurred during the Late Cretaceous-Eocene, before an acceleration of slab retreat changed the subduction regime and caused collapse of the Hellenic mountain belt and thinning of the Aegean Sea from Oligocene to the present (JOLIVET \& BRUN, 2010). During this post-orogenic episode large scale detachments formed which exhumed metamorphic core complexes in a back-arc setting. Tertiary to Quaternary calc-alkaline to alkaline magmatism in the Aegean region occurred mostly in a post-collisional setting behind the active Hellenic subduction zone (PE-PIPER \& PIPER, 2001). Lithospheric delamination, roll-back and/or break-off of the subducting slab were the principal mechanisms resulting in magma generation, which was triggered by asthenospheric mantle upwelling (JOLIVET \& BRUN, 2010).

In this geotectonic regime, large ore deposits of economic importance were formed during the Tertiary, in relation to magmatism and the evolution of extensive magmatic-hydrothermal systems. The ore types include reduced intrusion-related, skarn, porphyry, high-, intermediate- and low-sulfidation epithermal, carbonate-hosted replacement $\mathrm{Pb}-\mathrm{Zn}$ and polymetallic vein deposits (MELFOS et al., 2002; VOUDOURIS \& ALFIERIS, 2005; VOUDOURIS, 2006; BONSALL et al., 2011; MELFOS \& VOUDOURIS, 2012; VOUDOURIS et al., 2013a). They are concentrated into four regional metallogenic regions: 1) the Rhodope metallogenic province (RMP), 2) the Serbomacedonian metallogenic province (SMMP), 3) the Atticocycladic metallogenic province (ACMP) and 4) the Eastern Aegean metallogenic province (EAMP). These regions are the most promising targets for the near future exploration and exploitation of precious, rare and critical metals in Greece.

Tertiary basins and magmatic settings in the Rhodope massif are associated with significant skarn, polymetallic vein, porphyry and epithermal ore deposits, which are occasionally rich in Au and critical metals (MELFOS et al., 2002; VOUDOURIS, 2006; VOUDOURIS et al., 2009, 2011, 2013b), which constitute a part of the Rhodope metallogenic province. The magmatic-hydrothermal deposits of the Rhodope metallogenic province were formed during the final stage of the Tertiary orogenic collapse, and are related to the emplacement of hot asthenosphere into shallow crustal levels above a detached lithospheric plate which generated widespread magmatism (DE BOORDER et al., 1998; BLUNDELL et al., 2005). The Oligocene-Miocene magmas were intruded to shallow depths along deep seated detachment faults, forming mafic to felsic mantle-derived plutonic, subvolcanic and volcanic rocks of calc-alkaline, high-K calc-alkaline and shoshonitic to ultrapotassic (lamprophyric) affinities (CHRISTOFIDES, 1996; MARCHEV et al., 2005).

\section{FLUID INCLUSION CASE STUDIES}

\subsection{KAVALA INTRUSION-RELATED GOLD SYSTEM}

The Kavala intrusion-related gold system (IRGS) is part of the Palea Kavala ore system (Fig. 1) which includes $\sim 150$ ore mineralizations occurring either as primary hypogene quartzcalcite-sulfide veins or as supergene oxidized ore bodies, associated with the $21-22$ Ma granodioritic Kavala pluton of Itype (FORNADEL et al., 2011). This pluton intruded marbles, schists, amphibolites and gneisses of the Palaeozoic Rhodope metamorphic core complex, along the regional E-W trending Kavala-Xanthi-Komotini fault (Fig. 1). The mineralization is considered to be part of an intrusion-related ore system in overlapping zones centred on the pluton. The marble hosts distal oxidized Fe-Mn $(\mathrm{Pb} \pm \mathrm{Zn} \pm \mathrm{Ag})$ and Fe-Mn-Au ore bodies, whereas the gneiss and pluton contain proximal $\mathrm{Fe}-\mathrm{Cu}-\mathrm{Au}, \mathrm{Fe}-$ $\mathrm{As}-\mathrm{Au}$ and $\mathrm{Bi}-\mathrm{Te}-\mathrm{Au}$ vein mineralization. These ore mineralizations were exploited in ancient times for gold and silver with extensive underground and surface mining operations (VAVELIDIS et al., 1996).
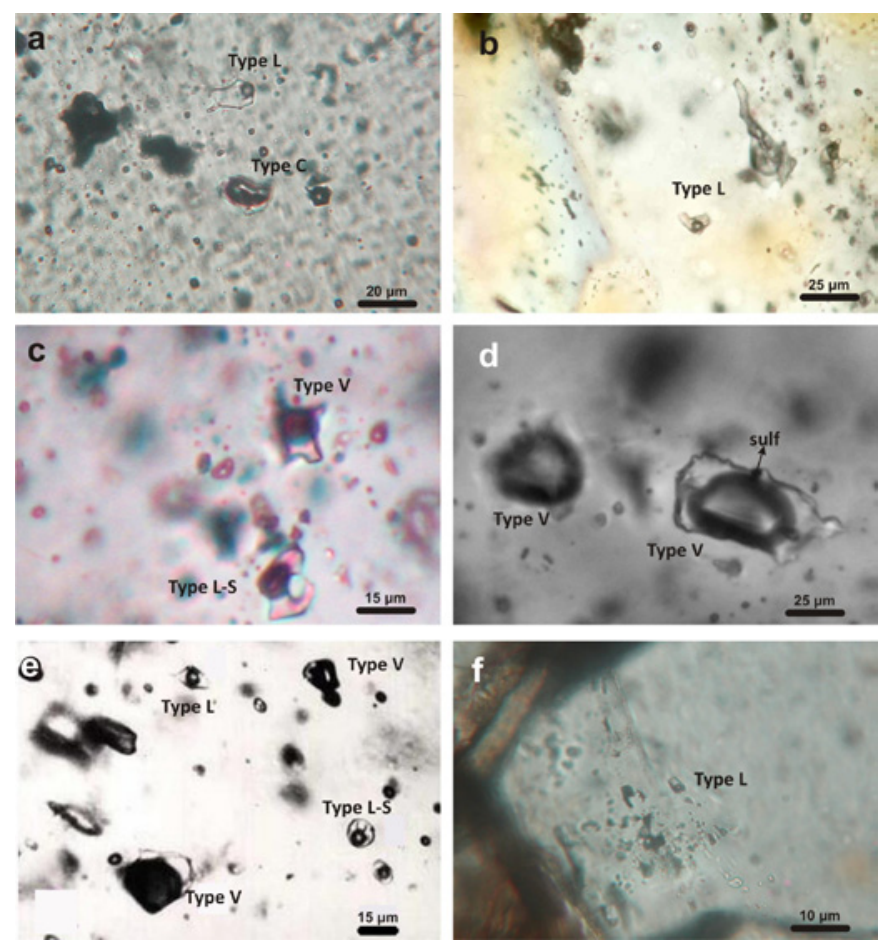

Figure 2. Fluid inclusion types from Tertiary ore mineralizations in the Rhodope metallogenic province, NE Greece. a. Type L two phase aqueous liquid-vapour fluid inclusion coexisting with type $\mathrm{C}$ three phase inclusion which contain $\mathrm{H}_{2} \mathrm{O}-\mathrm{CO}_{2}$, in Kavala sheeted vein system in the pluton; b. Type L two phase, liquid and vapour, fluid inclusion in a quartz vein at Eptadendro/Rachi; c. Type V vapour-rich two-phase aqueous inclusion coexisting with type L-S inclusion which contain three phases: a liquid, a vapour and a halite crystal in Pagoni Rachi porphyry system, indicating that they originate from a deep near-critical single phase fluid by phase separation; d. Type V two-phase vapourrich inclusion with an opaque daughter crystal possibly chalcopyrite in Pagoni Rachi porphyry system; e. Type V vapour-rich two-phase aqueous inclusion coexisting with type L-S inclusion which contain three phases: a liquid, a vapour and a halite crystal, and type L two phase aqueous liquid-vapour fluid inclusion in Maronia porphyry system; f. Type $\mathrm{L}$ aqueous liquid rich fluid inclusions which contain mainly $\mathrm{NaCl}$ in quartz at Perama Hill epithermal deposit. 
The SE-NW trending $\mathrm{Bi}-\mathrm{Te} \pm \mathrm{Pb} \pm \mathrm{Sb} \pm \mathrm{Au}$ quartz sheeted veins crosscut the pluton and the neighbouring metamorphic rocks in the Chalkero area, and contain pyrite, tetradymite, bismuthinite, cosalite and Sb-lillianite (FORNADEL et al., 2011). The veins consist of quartz, K-feldspar, albite and muscovite, altered to sericite and kaolinite. Fluid inclusions in these veins (Tab. 1) are rounded in shape, consistently distributed throughout the samples with a length of up to $60 \mu \mathrm{m}$ (with the majority in the 25 to $35 \mu \mathrm{m}$ range). They are classified into three types which coexist in each sample (MELFOS et al., 2008; FORNADEL et al., 2011) and therefore belong to the same primary fluid inclusion assemblage based on the criteria of GOLDSTEIN \& REYNOLDS (1994).

Type L contains two phase aqueous liquid-vapour fluid inclusions (Fig. 2a) with $\mathrm{NaCl}$ and $\mathrm{CaCl}_{2}$ and $20-30$ volume \% vapour. Homogenization temperatures range between $216^{\circ}$ and $420^{\circ} \mathrm{C}$, with a maximum at $380^{\circ} \mathrm{C}$, and the salinities vary from 15.9 to $22.6 \mathrm{wt} \% \mathrm{NaCl}$ equiv. Type $\mathrm{C}$ inclusions (Fig. 2a) are three phase: aqueous liquid, $\mathrm{CO}_{2}$-liquid, $\mathrm{CO}_{2}$-vapour approximately 50-70 volume \%, with minor $\mathrm{CH}_{4}$. They homogenize at $255^{\circ}-414^{\circ} \mathrm{C}$, with a peak at $320^{\circ} \mathrm{C}$, demonstrating salinities from 5.5 to $11.2 \mathrm{wt} \% \mathrm{NaCl}$ equiv. The third type $\mathrm{V}$ consists of two phase aqueous vapour-liquid fluid inclusions with a bubble of $90-95 \%$, which homogenized to the vapour phase at $\mathrm{Th}$ between $210^{\circ}$ and $323^{\circ} \mathrm{C}\left(\max =280^{\circ} \mathrm{C}\right)$.

The three fluid inclusion types are considered to represent coexisting immiscible carbonic and aqueous ore forming fluids (Fig. 3a). Isochores for fluid inclusions within the Kavala veins revealed a depth of formation, between 3 and $5 \mathrm{~km}$ (MELFOS et al., 2008; FORNADEL et al., 2011). Carbon dioxide played a significant role in the ore mineral precipitation in the Kavala veins.

\subsection{ASIMOTRYPES CARBONATEREPLACEMENT AND VEIN TYPE AU DEPOSIT AT PANGEON MOUNTAIN}

The Pangeon mountain includes numerous carbonate replacement, vein and shear-hosted $\mathrm{Au}-\mathrm{Ag}$ ore mineralizations, which were mined intensively during ancient times for gold and silver (VAXEVANOPOULOS et al., in press). They are hosted in the marbles and gneisses of the Rhodope massif as well as in the Pangeon granitoids.

One of the most important ore mineralizations occurs in Asimotrypes (Fig. 1) which is hosted in the Nikisiani pluton, part of the Pangeon granitoids, and in the marbles of the Rhodope massif (ELIOPOULOS, 2000; ELIOPOULOS \& KIL-
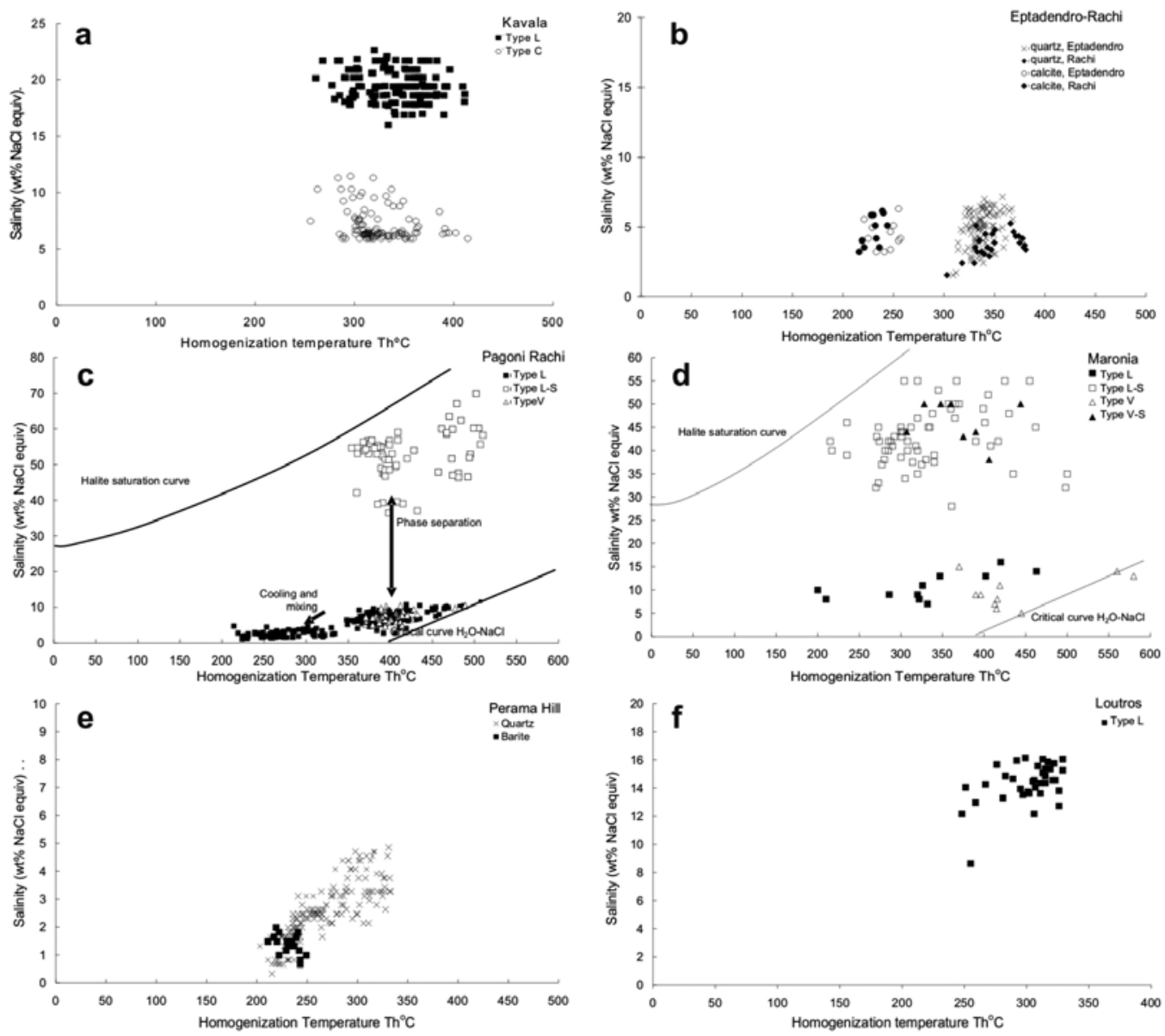

Figure 3. Homogenization temperatures versus salinity plots of fluid inclusions from various Tertiary ore mineralizations in the the Rhodope metallogenic province, NE Greece. a. Kavala intrusion related sheeted quartz veins $(n=241)$; b. Eptadendro/Rachi mineralized quartz veins $(n=249)$; c. Pagoni Rachi porphyry system overprinted by epithermal veins $(n=362)$; $d$. Maronia porphyry system overprinted by epithermal veins $(n=90)$; e. Perama Hill HS-IS epithermal system $(n=141)$; f. Loutros IS epithermal system $(n=36) . n=$ number of measurements. 
IAS, 2011; VAXEVANOPOULOS et al., in press). The Pangeon granitoids consist of tonalite, granodiorite and granite. They demonstrate characteristics of high-K calc-alkaline metaluminous to slightly peraluminous post-collisional rocks and have a hornblende ${ }^{40} \mathrm{Ar} /{ }^{39} \mathrm{Ar}$ age of 21 to $22 \mathrm{Ma}$ (ELEFTHERIADIS \& KORONEOS, 2003).

The mineralization is associated with structurally controlled quartz veins, pods and lenses, and in gold-bearing replacement bodies, and is partly oxidized. It consists mainly of pyrite and arsenopyrite, with minor galena, sphalerite, chalcopyrite, pyrrhotite, tetrahedrite-tennantite, marcasite and gold (ELIOPOULOS, 2000; VAXEVANOPOULOS et al., in press). Fluid inclusions are irregular to euhedral in shape with smooth boundaries reaching in size up to $20 \mu \mathrm{m}$.

Three types of primary fluid inclusions (Tab. 1) were distinguished by ELIOPOULOS (2000) and coexist in each sample being in equilibrium with the sulfide minerals. Type $\mathrm{L}$ contains two phase aqueous liquid-vapour fluid inclusions with $\mathrm{NaCl}$. The bubble occupies $10-20$ volume $\%$ and the homogenization temperatures range from $135^{\circ}$ to $256^{\circ} \mathrm{C}$ with a peak at $190^{\circ} \mathrm{C}$ and salinities from 5.62 to $9.05 \mathrm{wt} \% \mathrm{NaCl}$ equiv. Type $\mathrm{C}$ inclusions are three phase and contain liquid $\mathrm{H}_{2} \mathrm{O}$-rich, liquid $\mathrm{CO}_{2}$ and vapour $\mathrm{CO}_{2}$ ( 70 to $90 \%$ by volume). They homogenize at temperatures between $275^{\circ}$ and $340^{\circ} \mathrm{C}$, with a maximum at $320^{\circ} \mathrm{C}$, and show salinities from 2.61 to $7.31 \mathrm{wt} \% \mathrm{NaCl}$ equiv. The third type $\mathrm{V}$ consists of two phase aqueous vapour-liquid fluid inclusions which show decrepitation or leaking and no microthermometric measurements were achieved.

The gold mineralization was formed by coexisting immiscible carbonic and aqueous fluids at pressures of 1.8 to 2.0 kbars under lithostatic conditions corresponding to depths of 6 to $9 \mathrm{~km}$ with the ore fluids at $270^{\circ} \mathrm{C}$ (ELIOPOULOS \& KILIAS, 2011).

\subsection{EPTADENDRO-RACHI VEIN TYPE Ag-Au ORE MINERALIZATION}

The Cu-rich sulfide mineralization at the Eptadendro-Rachi ore district in Thrace, NE Greece, occurs at the contacts between granitoid intrusions (trodhjemites and pegmatites) of Upper Cretaceous to Early Tertiary age, and the meta-ultrabasic to basic rocks of the eastern Rhodope massif (Fig. 1). According to CHATZIKIRKOU \& MICHAILIDIS (2004) the ore bodies form quartz veins with pyrite, chalcopyrite, sphalerite, galena, hessite, bismuthinite, emplectite, tetradymite, aikinite, wittichenite, siegenite, millerite, bornite, pyrrhotite, covellite, magnetite, haematite and goethite. Chlorite, calcite and sericite are the alteration minerals associated with the vein mineralization.

Fluid inclusions have negative crystal or rounded to elongated isometric shapes with a length up to $42 \mu \mathrm{m}$, and are distributed along crystal faces of quartz and therefore are suggested to have a primary origin (MELFOS et al., 2010). At room temperature they contain two phases, a liquid and a vapour phase which occupies $20-30 \%$ by volume. Two fluid inclusion assemblages (FIAs) were identified MELFOS et al. (2010). The first FIA is hosted in quartz and is characterized by two phase, liquid and vapour, inclusions (Type L, Fig. 2b) at room temperature which homogenize to liquid at temperatures from $300^{\circ}$ to $380^{\circ} \mathrm{C}$, with a peak at $330^{\circ} \mathrm{C}$, and exhibit low salinities, 1.6 to $7.2 \mathrm{wt} \% \mathrm{NaCl}$ equiv, corresponding to the fluids of the main ore stage.

The second FIA also include two phase fluid inclusions (Type L) and are distinguished by a drop in $\mathrm{Th}\left(210^{\circ}\right.$ to $260^{\circ} \mathrm{C}$, with a peak at $240^{\circ} \mathrm{C}$ ) corresponding to the late ore stage associated with calcite formation, whereas the salinities (3.2 to $6.3 \mathrm{wt} \% \mathrm{NaCl}$ equiv) are similar to the first FIA. $\mathrm{NaCl}$ is the dominant salt component of the fluids.

The low to moderate salinities (1.6 to $7.2 \mathrm{wt} \% \mathrm{NaCl}$ equiv) of the two FIAs are possibly attributed to mixing between ascending magmatic fluids and downward migrating dilute meteoric water. According to MELFOS et al. (2010) such a process is very likely in a hydrothermal environment with a fault-controlled vein structure and causes ore deposition by diluted fluids at decreasing temperatures, from $380^{\circ}$ to $210^{\circ} \mathrm{C}$ (Fig. 3b).

\subsection{THASOS (KAPSALINAAND PANAGIA) VEIN TYPE ORE MINERALIZATIONS}

Thasos has been mined for Au and Ag both during antiquity, and in the $20^{\text {th }}$ century (VAVELIDIS et al., 1988). Silver rich carbonate $\mathrm{Pb}-\mathrm{Zn}$ replacement deposits occur at the western part of the island, whereas $\mathrm{Cu}-\mathrm{Au}$ and gold deposits exist at the northeastern and eastern part of the island (VAVELIDIS \& AMSTUTZ, 1983). Two Cu-Bi-Ag $\pm \mathrm{Te}$ mineralizations on Thasos island, in Kapsalina and Panagia areas (Fig. 1) have been described by VAVELIDIS et al. (1995) and VAVELIDIS \& MELFOS (2004).

The Kapsalina copper mineralization is hosted in quartz veins which crosscut the schists of the Rhodope massif. The ore mineralization consists mainly of chalcopyrite and pyrite, with minor bismuthinite, tetrahedrite-tennantite and gersdorffite (VAVELIDIS \& MELFOS, 2004). Fluid inclusions were studied in quartz from the mineralized veins and were identified as primary and pseudosecondary. Their size ranges from 4 to $45 \mu \mathrm{m}$, mainly up to $10 \mu \mathrm{m}$. Based on their phase assemblages at room temperature one type of inclusion (Type L) was distinguished containing a liquid aqueous solution and a vapour bubble (approximately 10 volume \%). The fluid is dominated by $\mathrm{NaCl}$ with a minor contribution of $\mathrm{KCl}$ demonstrating salinities from 1.0 to $3.3 \mathrm{wt} \% \mathrm{NaCl}$ equiv. Homogenization temperatures of the fluid inclusions vary mainly from 120 to $280^{\circ} \mathrm{C}$, with a peak at $200^{\circ} \mathrm{C}$ (VAVELIDIS \& MELFOS, 2004). The mineralization was formed by cooling of the hydrothermal fluids which were derived mainly by meteoric waters.

The mineralization in Panagia is hosted in quartz veins which crosscut the schists, marbles, dolomitic marbles, amphibolites and gneisses of the Rhodope massif. The mineralization consists of chalcopyrite, pyrrhotite, pyrite, tetrahedrite-tennantite, gersdorffite, tetradymite and hessite.

Microthermometric measurements were carried out on fluid inclusions of the mineralized quartz (VAVELIDIS et al., 1995). Based on their phase proportions at room temperature, three types of fluid inclusions were distinguished which belong to the same primary fluid inclusion assemblage based on the criteria of GOLDSTEIN \& REYNOLDS (1994). Fluid inclusions of type L (up to $18 \mu \mathrm{m}$ in length) consist of liquid rich two- 
phase inclusions which contained mainly $\mathrm{NaCl}$ and the vapour ranges from 10 to $20 \%$ in volume. The homogenization temperatures vary between $229^{\circ}$ and $305^{\circ} \mathrm{C}$, with a maximum at $290^{\circ} \mathrm{C}$ and the salinities are low, from 3.12 to $3.28 \mathrm{wt} \% \mathrm{NaCl}$ equiv.

The type C fluid inclusions, with a length up to $20 \mu \mathrm{m}$, contain three phases dominated by aqueous liquid, $\mathrm{CO}_{2}$-liquid and $\mathrm{CO}_{2}$-vapour approximately $60-70 \%$ of the total volume. A total fluid salinity of 3.7 to $6.5 \mathrm{wt} \% \mathrm{NaCl}$ equiv was estimated. Final homogenization temperatures of this type of inclusions vary from 313 and $360^{\circ} \mathrm{C}$, with a maximum at $330^{\circ} \mathrm{C}$. A third type of fluid inclusion is made up by large irregularly shaped cavities, which contain pure $\mathrm{CO}_{2}$. The vein type mineralizations in Panagia were formed by two coexisting immiscible carbonic and aqueous fluids and $\mathrm{CO}_{2}$ played a significant role in the ore precipitation.

\subsection{PAGONI RACHI PORPHYRY Cu-Mo-Re-Au DEPOSIT}

The Pagoni Rachi Cu-Mo-Re-Au mineralization (Fig. 1) belongs to the Kirki mining district and is a telescoped porphyry-epithermal system which is spatially related to calc-alkaline granodiorite-tonalite porphyry stock of Oligocene age (VOUDOURIS et al., 2013b). Alteration types and vein relationships suggest that mineralization can be divided into four paragenetic stages, which are, from early to late: (1) sodic/ potassic-calcic alteration with quartz- and magnetite-bearing veins (A- and M-type) and distal propylitic alteration, (2) so$\mathrm{dic} /$ potassic alteration with quartz-pyrite-chalcopyrite-molybdenite veins (B-type), (3) sericitic alteration with "transitional" porphyry to epithermal pyrite-chalcopyrite-molybdenite veins (D-type), and (4) argillic alteration with quartzcalcite base metal and precious metal rich veins (E-type) with epithermal affinity. The mineralization contains molybdenite with up to $4.7 \mathrm{wt} \% \mathrm{Re}$ and the rare mineral rheniite (VOUDOURIS et al., 2009, 2013b).

Fluid inclusions were studied in the various vein types (A, $\mathrm{B}$, and $\mathrm{E}$ ) and are in equilibrium with the sulfide minerals and therefore represent the ore forming fluids (VOUDOURIS et al., 2013b). Their maximum size is $30 \mu \mathrm{m}$ (mainly between 7 and $15 \mu \mathrm{m}$ ). They are isolated or arranged along quartz and calcite growth zones and are considered to have a primary origin based on the criteria of BODNAR (2003).

Three types of primary fluid inclusions were identified (VOUDOURIS et al., 2013b). Type L consists of two-phase aqueous inclusions with a vapour bubble occupying 10 to 20 volume $\%$, which homogenize to a liquid phase. Type L-S inclusions contain three phases: a liquid, a vapour (10 to 20 volume \%) and a halite crystal (Fig. 2c). Type V inclusions are two-phase vapour-rich $(\sim 80$ volume $\%)$ aqueous inclusions (Fig. 2c,d). They homogenize to the vapour phase. They commonly contain an accidental-trapped opaque crystal (Fig. 2d) possibly chalcopyrite (VOUDOURIS et al., 2013b). Three distinct primary fluid inclusion assemblages (FIAs) were identified (VOUDOURIS et al., 2009, 2013b). The first two assemblages contain coexisting L, L-S and V inclusion types in A- and B-veins. The third assemblage includes late type $\mathrm{L}$ inclusions in the epithermal E-veins.
A- and B-veins were deposited at temperatures ranging between 360 and $510^{\circ} \mathrm{C}$ and at pressures up to 690 bars $(<2$ $\mathrm{km}$ depth) for A-veins and up to 360 bars ( $<1.5 \mathrm{~km}$ depth) for B-veins, from boiling hydrothermal fluids. This process produced coexisting low to moderately saline (1.7-10.7 $\mathrm{wt} \%$ $\mathrm{NaCl}$ equiv) and highly saline (36-> $74 \mathrm{wt} \% \mathrm{NaCl}$ equiv) fluids (Fig. 3c). The fluid inclusions in the A- and B-type veins indicate that vapour was the predominant ore-forming fluid. Subsequent dilution of the moderately saline fluid resulted in a lower temperature $\left(210-340{ }^{\circ} \mathrm{C}\right)$, less saline $(1.4-2.9 \mathrm{wt} \%$ $\mathrm{NaCl}$ equiv) mineralizing fluid in late epithermal E-veins (Fig. 3c, VOUDOURIS et al., 2013b).

\subsection{MARONIA PORPHYRY Cu-Mo-Re-Au MINERALIZATION}

The Maronia Cu-Mo-Re-Au mineralization (Fig. 1) is hosted by a porphyritic microgranite (MELFOS et al., 2002). Three hydrothermal alteration zones have been recognized: an argillic, a sericitic and a propylitic zone. Additionally, three highly silicified zones crop out at the microgranite. Chalcopyrite-pyrite-molybdenite mineralization is located mainly in the silicified zones and is associated with areas of sericitic and propylitic alteration. The molybdenite revealed unusually high and variable rhenium concentrations (Re from 0.12 to $4.21 \mathrm{wt} \%$ ).

Fluid inclusions which were studied in the ore-related quartz (MELFOS et al., 2002) have rounded to elongated or negative-crystal shapes and are isolated or arranged along quartz demonstrating a primary origin. Their size reaches up to $60 \mu \mathrm{m}$. Four types of fluid inclusions were identified (MELFOS et al., 2002). Type L contains 2-phase aqueous liquid-rich inclusions (vapour 20-35 volume \%) and type L-S consists of 3-phases, an aqueous liquid phase, a vapour (2040 volume \%) and a halite $(\mathrm{NaCl})$ crystal (Fig. 2e). Type $\mathrm{V}$ inclusions are two-phase vapour-rich (70-90 volume \%), whereas type $\mathrm{V}-\mathrm{S}$ are 3 -phase aqueous vapour-rich (60-80 volume \%) inclusions with a daughter mineral (halite). Fluid inclusions, mainly types L and L-S contain an accidentallytrapped opaque phase (pyrite and/or chalcopyrite?), which suggests that they represent the mineralizing fluid at the Maronia deposit.

Microthermometric results from the porphyry system showed that propylitic alteration and associated magnetitepyrite-quartz veins are characterized by temperatures between 320 to $410^{\circ} \mathrm{C}$, with a mean at $400^{\circ} \mathrm{C}$. Trapping temperatures in the quartz-pyrite-chalcopyrite veins from sericitic alteration zone range from 360 to $420^{\circ} \mathrm{C}$, with a peak at $380^{\circ} \mathrm{C}$, and record the main temperature range of copper deposition under boiling conditions. Pyrite-molybdenite veins in sericitic zone were formed at slightly lower temperatures, from 250 to $360^{\circ} \mathrm{C}$, with a maximum at $340^{\circ} \mathrm{C}$. The ore-bearing fluids were dominated by $\mathrm{NaCl}$, with salinities ranging from 7.0 to $16.4 \mathrm{wt} \% \mathrm{NaCl}$ equiv in type $\mathrm{L}$ inclusions, from 28 to $55 \mathrm{wt} \% \mathrm{NaCl}$ equiv in L-S fluid inclusions, from 5.5 to $14.0 \mathrm{wt} \% \mathrm{NaCl}$ equiv in type $\mathrm{V}$ inclusions and from 38 to 51 $\mathrm{wt} \% \mathrm{NaCl}$ equiv in $\mathrm{V}-\mathrm{S}$ inclusions (Fig. 3d). Trapping pressures of the ore-forming fluids were estimated to vary from 150 to 510 bar and boiling along with cooling of the fluids are 
considered to be the main processes of ore formation (MELFOS et al., 2002).

\subsection{PERAMA HILL HS-IS EPITHERMAL Au-Ag DEPOSIT}

An epithermal mineralization rich in $\mathrm{Au}, \mathrm{Ag}$, Te and Se occurs in Perama Hill at the Petrota graben, NE Greece (Fig. 1). The ore mineralization is hosted in andesitic rocks and the overlying conglomerates and sandstones and exhibits characteristics of a high sulfidation system which was followed by deposition of an intermediate sulfidation mineralization (VOUDOURIS et al., 2011). It forms a sulfide rich vein-type in the andesite and a Au-rich stratabound oxidized type in the overlying sedimentary rocks. The ore mineral paragenesis includes a complex $\mathrm{Pb}-\mathrm{Zn}$-Bi-Se-Te-Sn-Au-Ag hypogene ore assemblage with native gold, native tellurium and electrum.

Fluid inclusions have negative-crystal or elongated isometric shapes with a maximum diameter of $30 \mu \mathrm{m}$, and were observed in quartz (Fig. 2f) and barite from the high sulfidation veins in andesite at depths of $88 \mathrm{~m}$ and $97 \mathrm{~m}$ (VOUDOURIS et al., 2011). They are aqueous liquid rich (Type L) with $\sim 20$ volume \% vapour and contain mainly $\mathrm{NaCl}$. They are isolated or arranged along the quartz or barite growth zones and consequently are defined as primary.

Homogenization temperatures in quartz vary from 211 to $331{ }^{\circ} \mathrm{C}$, with a maximum at $240^{\circ} \mathrm{C}$, and salinities from 0.7 to $4.9 \mathrm{wt} \% \mathrm{NaCl}$ equiv. In barite the inclusions display Th values of 222 to $256^{\circ} \mathrm{C}$, with a maximum at $240^{\circ} \mathrm{C}$, overlapping those of quartz, and very low salinities, between 0.8 and 2.3 $\mathrm{wt} \% \mathrm{NaCl}$ equiv. The mineralization was formed by cooling and dilution of the ore fluids which were possibly derived by condensation of magmatic vapour with limited mixing with meteoric water between a higher temperature $\left(330^{\circ} \mathrm{C}\right)$ and a higher salinity ( $4.9 \mathrm{wt} \% \mathrm{NaCl}$ equiv) end-member and a lower temperature $\left(210^{\circ} \mathrm{C}\right)$ dilute $(0.7 \mathrm{wt} \% \mathrm{NaCl}$ equiv) component (Fig. 3e, VOUDOURIS et al., 2011).

\subsection{LOUTROS HILL IS EPITHERMAL Ag DEPOSIT}

The Loutros area belongs at the Feres-Soufli-Dadia volcanosedimentary basin. An intermediate sulfidation epithermal mineralization (Fig. 1) is associated with a zeolite-altered rhyolitic lava dome which demonstrates an age of $19.5 \mathrm{Ma}$ (whole rock K/Ar geochronology, CHRISTOFIDES et al., 2004). The ore mineralization consists mainly of pyrite and marcasite and occurs either in the form of hydrothermal breccias or in NW-trending massive or barite bearing veins. Rarely barite-galena veins with sphalerite and minor chalcopyrite crosscut the rhyolite. The mineralized barite veins are enriched in Mo (up to $\leq 15.6 \mathrm{~g} / \mathrm{t}$ ), As (up to $1058 \mathrm{~g} / \mathrm{t}$ ) and $\mathrm{Ag}$ (up to $31 \mathrm{~g} / \mathrm{t}$ ).

Fluid inclusions with irregular elongated shapes and a size up to $25 \mu \mathrm{m}$, were observed in barite and are represented by type $\mathrm{L}$ which contains an aqueous liquid rich phase (10-20 volume \% vapour). Microthermometric results revealed a homogenization temperature range mainly between $220^{\circ}$ and $329^{\circ} \mathrm{C}$, with a maximum at $310^{\circ} \mathrm{C}$, and salinities from 8.65 to $16.14 \mathrm{wt} \% \mathrm{NaCl}$ equiv (unpublished data). The formation of the mineralization is attributed to cooling of an ore magmatic fluid, dominated by $\mathrm{NaCl}$, and a possible limited mixing with meteoric water at 330 to $220^{\circ} \mathrm{C}$ (Fig. 3f).

\section{DISCUSSION}

Based on phase composition at room temperature, five types of fluid inclusions were identified in quartz, calcite and barite from magmatic-hydrothermal ore mineralizations in the Rhodope metallogenic province in NE Greece: (1) Type L - twophase fluid inclusions consisting of an aqueous (low-salinity) solution with a vapour bubble with $\mathrm{NaCl}$ and sometimes minor $\mathrm{CaCl}_{2}$; (2) Type $\mathrm{C}$ - three phase inclusions which contain $\mathrm{H}_{2} \mathrm{O}$ $\mathrm{CO}_{2}$, sometimes with occasional $\mathrm{CH}_{4}$; (3) Type $\mathrm{V}$ - two phase aqueous vapour-liquid fluid inclusions; (4) Type L-S - multiphase phase inclusions which contain an aqueous solution, a vapour bubble and a halite crystal; (5) Type V-S - three phase aqueous vapour-rich inclusions with a halite crystal. At the porphyry mineralizations L and L-S fluid inclusions contain a pyrite or chalcopyrite crystal which shows that they represent the mineralizing fluid (ROEDDER, 1977; BORTNIKOV, 2006). However not all types of fluid inclusions occur in all ore mineralizations, suggesting that they formed from fluids of different composition and under various conditions (Table 1).

Fluid inclusions in the Kavala reduced intrusion related sheeted vein system hosting a $\mathrm{Bi}-\mathrm{Te}-\mathrm{Pb}-\mathrm{Sb}-\mathrm{Au}$ mineralization, display a range of fluid compositions (Types $\mathrm{L}, \mathrm{C}$ ). Inclusions with low to moderate salinities ( 5.5 to $11.2 \mathrm{wt} \% \mathrm{NaCl}$ equiv) $\mathrm{CO}_{2}$-rich fluids are common and co-exist with moderate to high salinity fluids (salinities 15.9 to $22.6 \mathrm{wt} \% \mathrm{NaCl}$ equiv). Methane is detectable in the $\mathrm{CO}_{2}$-rich fluid inclusions. Kavala veins are characterized as a deep seated system ( $\sim 3$ to $5 \mathrm{~km})$ which was formed by two co-existing high temperature $\left(\mathrm{Th}=300^{\circ}\right.$ and $\left.400^{\circ} \mathrm{C}\right)$, moderate to high salinity, immiscible carbonic and aqueous fluids (FORNADEL et al., 2011).

Fluid inclusions from Asimotrypes carbonate replacement mineralization at Pangaion mountain demonstrate the co-existence of two immiscible fluids, a low to moderate (2.61 to 7.31 $\mathrm{wt} \% \mathrm{NaCl}$ equiv) carbonic fluid and a moderate salinity (5.62 to $9.05 \mathrm{wt} \% \mathrm{NaCl}$ equiv) aqueous fluid. ELIOPOULOS \& KILIAS (2011) have shown that the main cause of ore precipitation should be attributed to unmixing of two fluids, a carbonic and an aqueous, at depths from 6 to $9 \mathrm{~km}$ at $\sim 270^{\circ} \mathrm{C}$. In the quartz veins at Panagia of Thasos the fluids are dominated by two immiscible fluids, an aqueous-carbonic and an aqueous fluid, which have low to moderate salinities (3.7 to $6.5 \mathrm{wt} \%$ eq. $\mathrm{NaCl}$ ) and trapping temperatures from $340^{\circ}$ to $360^{\circ} \mathrm{C}$ at 500 $700 \mathrm{kbar}$ (VAVELIDIS et al., 1995). The presence of Te and the elevated temperatures of the Panagia vein system possibly show that it is located proximally to a magmatic rock, which however is not exposed on Thasos island but can only be assumed.

Kavala, Asimotrypes and Panagia ore systems show many similarities regarding their fluid characteristics. According to the intrusion related model presented by HART (2005) the Kavala sheeted veins in the pluton and the adjacent metamorphic rocks represent the most proximal system, whereas Asimotrypes carbonate replacement mineralization occurs at some distance from the Nikisiani pluton, being part of an intrusionrelated gold system (IRGS). Panagia vein mineralization at 


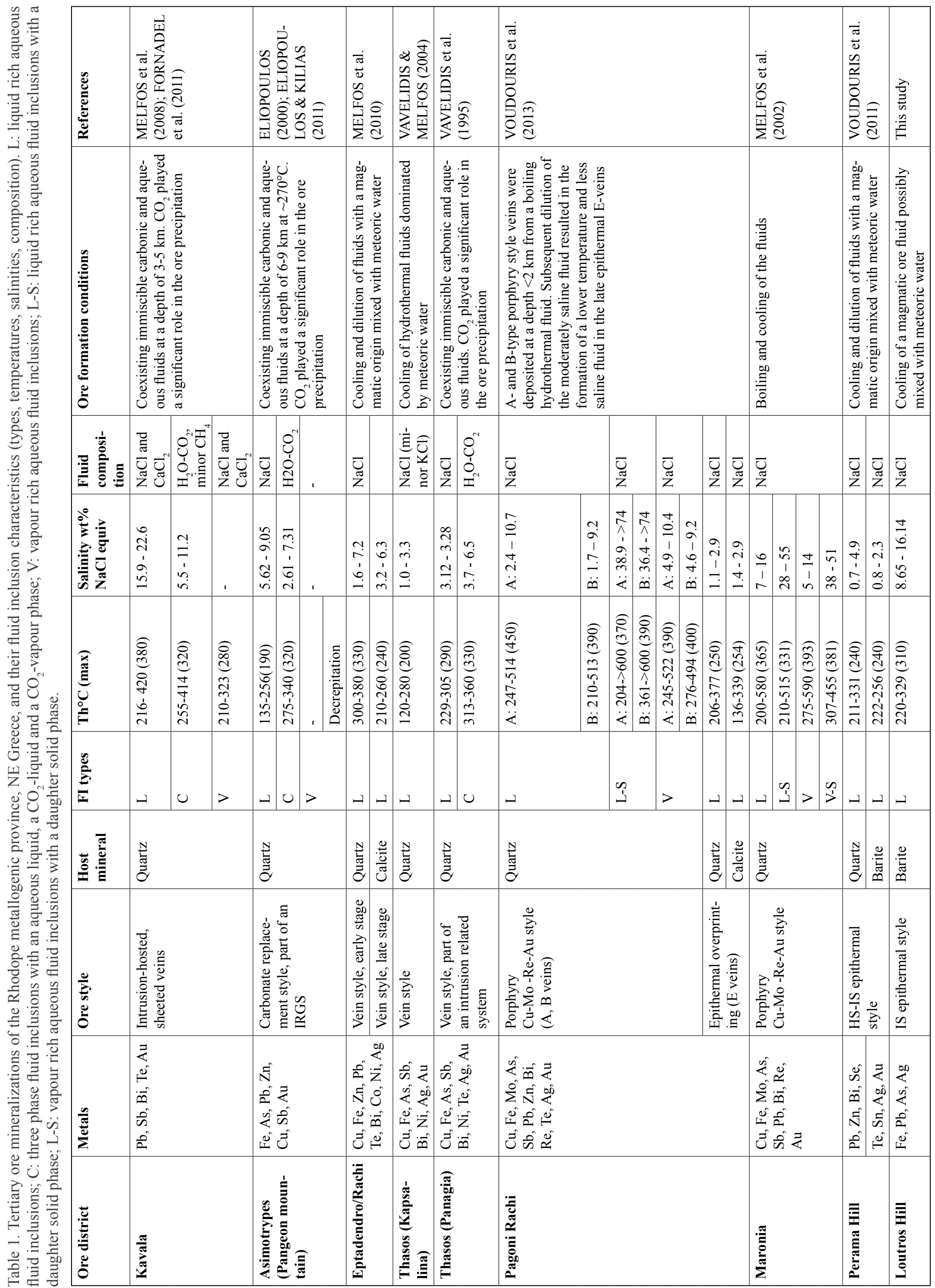


Thasos island also demonstrates features which are similar to an IRGS, although there is no plutonic rock occurrence on the island.

In these three systems aqueous-carbonic and aqueous fluids coexist in the same samples, demonstrating that carbon dioxide played a significant role in ore formation. It has been emphasized that $\mathrm{CO}_{2}$ is the medium which can induce transport and precipitation of some metals, including gold, and aids the process of ore deposition by phase separation in magmatichydrothermal systems (LANG \& BAKER, 2001; BAKER, 2002). This process is common in many intrusion related gold systems and has been cited as direct evidence for a magmatic fluid source (BAKER \& LANG, 2001), although decarbonization reactions in wall-rock and dissolution of $\mathrm{CO}_{2}$ from crustal hydrothermal fluids may be also encountered (LOWENSTERN, 2001).

Vein type ore mineralizations in the Rhodope metallogenic province are fault-controlled vein structures. They show similar formation conditions (temperatures-salinities), but relatively different fluid chemical compositions. In the EptadendroRachi vein system the mineralization was caused by mixing between ascending magmatic fluids and downward migrating dilute meteoric water during cooling at homogenization temperatures from $380^{\circ}$ to $210^{\circ} \mathrm{C}$. These fluids with low to moderate salinities (1.6-7.2 $\mathrm{wt} \% \mathrm{NaCl}$ equiv) probably show an association with a granitoid body at depth, of Tertiary age, which is not exposed at the surface. The mineralized veins in Kapsalina of Thasos island were formed under similar conditions by low to moderate temperatures and low density fluids ( $\mathrm{Th}=120$ $280^{\circ} \mathrm{C}$, salinities $=1.0-3.3 \mathrm{wt} \% \mathrm{NaCl}$ equiv) also by cooling of the hydrothermal fluids which were derived mainly by meteoric waters (VAVELIDIS \& MELFOS, 2004).

The porphyry Cu-Mo-Re-Au ore systems in Pagoni Rachi and Maronia demonstrate the contribution of the vapour phase and the highly saline fluids under boiling conditions for ore mineral precipitation. Boiling processes resulted in the generation of coexisting low to moderately saline and highly saline fluids at temperatures from 300 to $500^{\circ} \mathrm{C}$ and the formation of the different hydrothermal alteration and ore zones (MELFOS et al., 2002; VOUDOURIS et al., 2013b). Vapour and brine dominance in both porphyry systems indicate that they originate from a deep near-critical single phase fluid by decompression and subsequent phase separation. In this case a low-density magmatic vapour phase is the principal agent for metal transportation, according to the model proposed by HEINRICH (2005), WILLIAMS-JONES \& HEINRICH (2005), HURTIG \& WILLIAMS-JONES (2015).

The released magmatic derived vapour rich fluids can transport high concentrations of metals mainly $\mathrm{Cu}$ and Au. Rapid expansion of vapour at a shallow depth favours $\mathrm{Cu}, \mathrm{Fe}, \mathrm{Mo}, \mathrm{Re}$ and $\mathrm{Au}$ saturation and precipitation of the related ore minerals. WILLIAMS-JONES \& HEINRICH (2005) emphasize the role of vapour volatile and precipitation of the bulk of $\mathrm{Cu}, \mathrm{Au}$ and Mo at temperatures between 320 and $425^{\circ} \mathrm{C}$ at a shallow depth of about $2 \mathrm{~km}$. At this temperature in the presence of iron, $\mathrm{SO}_{2}$ in the fluid phase is reduced to $\mathrm{H}_{2} \mathrm{~S}$ and $\mathrm{H}_{2} \mathrm{SO}_{4}$, which favours the precipitation of sulfides, especially pyrite, chalcopyrite, bornite and molybdenite, and increases gold solubility. The same process decreases drastically the fluid $\mathrm{pH}$ and causes the generation of an increasingly acidic fluid, which is associated with the related hydrothermal alteration minerals, mainly sericite and after mixing with groundwater, kaolinite (HEINRICH, 2005).

The shallow epithermal veins in the Pagoni Rachi porphyry system and the epithermal overprinting identified in Maronia (MELFOS et al., 2002; VOUDOURIS et al., 2013b) were formed under lower temperature conditions due to cooling and dilution of the ore fluids, which were evolved from initial high temperature and low salinity fluids towards cooler and very low salinity hydrothermal fluids.

The Perama Hill HS-IS and the Loutros IS epithermal mineralizations show similar temperature conditions $\left(220-330^{\circ} \mathrm{C}\right)$ but slightly different salinities. In Perama Hill the salinities range between 0.7 to $4.9 \mathrm{wt} \% \mathrm{NaCl}$ equiv indicating condensation of a magmatic vapour in the hydrothermal fluid with limited mixing with a fluid that had a major meteoric water component. In Loutros the salinities are higher (8.65 to 16.14 $w t \% \mathrm{NaCl}$ equiv) which show a significant magmatic contribution in the hydrothermal fluid with possibly a limited mixing with meteoric water. The epithermal mineralizations in Perama Hill and Loutros were formed by cooling and dilution of the ore fluids. These fluids may represent late stage magmatic fluids that probably mixed with meteoric or seawater fluids at shallow levels.

\section{CONCLUSIONS}

Fluid inclusion studies of Tertiary magmatic-hydrothermal ore mineralizations in the Rhodope metallogenic province, NE Greece, focus mainly on the chemical composition of the ore forming fluids and the formation conditions of the mineralizations, the role of the magmatic and meteoric fluids and their possible interaction for the metallogenesis, the immiscibility and boiling processes and the role of $\mathrm{CO}_{2}$ in ore precipitation. The different fluid characteristics and microthermometric data indicate a variety of fluid origin conditions and sources which can affect the strategy for exploration and prospecting of ore deposits.

Carbon dioxide rich hydrothermal fluids and $\mathrm{Au}$ and $\mathrm{Te}$ mineralization is common and occurs at the Kavala intrusion hosted sheeted vein system, at the Asimotrypes Au-rich carbonate replacement mineralization and at the Panagia (Thasos) vein system. Transport and precipitation of metals like Au and Te is favoured when $\mathrm{CO}_{2}$ is present. Precipitation of the ore mineralization takes place due to the immiscibility of the carbonic and the aqueous fluids resulting in their unmixing. These fluids have a magmatic origin with the contribution of meteoric water and are derived from deep seated systems. Based on geological and mineralogical criteria and the fluid inclusion data, we classify all these three ore mineralizations in Kavala, Asimotrypes and Panagia of Thasos, as parts of IRGS.

Cooling of magmatic hydrothermal fluids and dilution with meteoric water is a common cause of ore mineral formation in vein mineralizations (Eptadendro/Rachi, Kapsalina Thasos). Boiling and the vapour phase predominance are the most important processes for metallogenesis in the porphyry deposits (Pagoni Rachi and Maronia). These features are common in 
porphyry systems and the mining industry should focus on them during early stage exploration work.

The epithermal veins overprinting the Pagoni Rachi and the Maronia porphyry systems and the HS-IS epithermal system in Perama Hill and the IS epithermal mineralization in Loutros are characterized by low to moderate temperatures and low to moderate salinities. Cooling and dilution of the ore fluids are the main processes for gold precipitation.

Following these criteria of the fluid characteristics, exploration for gold, rare and critical metals could have encouraging results to promote the mining industry in the future by using fluid inclusion techniques.

\section{Acknowledgment}

The authors would like to thank the reviewer Ladislav PALINKAS $\breve{S}$ and an Anonymous Reviewer for their helpful and constructive comments on the manuscript. Ms Alisa MARTEK is especially thanked for her editorial handling of the paper.

\section{REFERENCES}

BAKER, T. \& LANG, J.R. (2001): Fluid inclusion characteristics of intrusionrelated gold mineralization, Tombstone-Tungsten magmatic belt, Yukon Territory, Canada.- Mineralium Deposita, 36, 563-582.

BAKER, T. (2002): Emplacement depth and carbon dioxide-rich fluid inclusions in intrusion-related gold deposits.- Economic Geology, 97, 1111-1117. doi: 10.2113/97.5.1111

BLUNDELL, D., ARNDT, N., COBBLOD P.R. \& HEINRICH, C. (2005): Processes of tectonism, magmatism and mineralization: Lessons from Europe.- Ore Geology Reviews, 27, 333-349. doi: 10.1016/j.oregeorev.2005.07.003

BODNAR, R.J. (2003): Introduction to fluid inclusions.- In: SAMSON, I.M., ANDERSON, A.J. \& MARSHALL, D.D. (eds.): Fluid inclusions: analysis and interpretation. Mineralogical Association of Canada Short Course, $32,1-8$.

BONSALL, T.A., SPRY, P.G., VOUDOURIS, P.C., TOMBROS, S., SEYMOUR, K.S. \& MELFOS, V. (2011): The geochemistry of carbonate-replacement $\mathrm{Pb}-\mathrm{Zn}-\mathrm{Ag}$ mineralization in the Lavrion district, Attica, Greece: Fluid inclusion, stable isotope, and rare earth element studies.Economic Geology, 106, 619-651. doi: 10.2113/econgeo.106.4.619

BORTNIKOV, N.S. (2006): Geochemistry and origin of the ore-forming fluids in hydrothermal-magmatic systems in tectonically active zones.- Geology of Ore Deposits, 48, 1-22. doi: 10.1134/S1075701506010016

CHANG, Z., HEDENQUIST, J.W., WHITE, N.C., COOKE, D.R., ROACH, M., DEYELL, C.L. \& CUISON, A.L. (2011): Exploration tools for linked porphyry and epithermal deposits: Example from the Mankayan intrusion-centered $\mathrm{Cu}-\mathrm{Au}$ district, Luzon, Philippines.- Economic Geology, 106, 1365-1398. doi: 10.2113/econgeo.106.8.1365

CHATZIKIRKOU, A. \& MICHAILIDIS K. (2004): The Eptadendro and Rachi sulfide mineralization, Eastern Rhodope, Greece.- Bull. Geol. Soc. Greece, 36, 397-405 (in Greek with English abstract).

CHRISTOFIDES, G. (1996): Tertiary magmatism in the Greek Rhodope Massif, northern Greece: Granitic plutons.- In: KNEZEVIC, V. \& KRSTIC B. (eds.): Terranes of Serbia: The Formation of the Geologic Framework of Serbia and the Adjacent Regions. University of Belgrade, Belgrade, $155-160$.

CHRISTOFIDES, G., PECSKAY, Z., ELEFTHERIADIS, G., SOLDATOS, T. KORONEOS, A. (2004): The Tertiary Evros volcanic rocks (Thrace, northeastern Greece): petrology and $\mathrm{K} / \mathrm{Ar}$ geochronology.- Geologica Carpathica, 55, 397-410.

DE BOORDER, H., SPAKMAN, W., WHITE, S.H. \& WORTEL, M.J.R. (1998): Late Cenozoic mineralization, orogenic collapse and slab detachment in the European Alpine Belt.- Earth and Planetary Science Letters, 164, 569-575. doi: 10.1016/S0012-821X(98)00247-7

ELEFTHERIADIS, G. \& KORONEOS, A. (2003): Geochemistry and petrogenesis of post-collision Pangeon granitoids in central Macedonia, Northern Greece.- Chemie der Erde-Geochemistry, 63, 364-389. doi: 10.1078/0009-2819-00024

ELIOPOULOS, D.G. \& KILIAS, S.P. (2011): Marble-hosted submicroscopic gold mineralization at Asimotrypes area, mount Pangeon, southern Rhodope core complex, Greece.- Economic Geology, 106, 751-780. doi: 10.2113/econgeo.106.5.751
ELIOPOULOS, D.G. (2000): Geochemistry and origin of the Asimotrypes carbonatehosted mesothermal gold deposit, Pangeon mountain, N. Greece.- Unpublished PhD thesis, University of Southampton, UK, 244 p.

FORNADEL, A.P., SPRY, P.G., MELFOS, V., VAVELIDIS, M. \& VOUDOURIS, P. (2011): Is the Palea Kavala $\mathrm{Bi}-\mathrm{Te}-\mathrm{Pb}-\mathrm{Sb} \pm \mathrm{Au}$ district, northeastern Greece, an intrusion-related system?- Ore Geology Reviews, 39, 119-133. doi: 10.1016/j.oregeorev.2011.01.002

GEORGAKOPOULOU, M., BASSIAKOS, Y. \& PHILANIOTOU, O. (2011): Seriphos surfaces: a study of copper slag heaps and copper sources in the context of Early Bronze Age Aegean metal production.- Archaeometry, 53, 123-145. doi: 10.1111/j.1475-4754.2010.00529.x

GOLDSTEIN, R.H. \& REYNOLDS, T.J. (1994): Systematics of fluid inclusions in diageneticminerals.- SEPM Short Course 31, Tulsa, 199 p.

HART, C.J.R. (2005): Classifying, distinguishing and exploring for intrusionrelated gold systems. The Gangue, Geological Association of Canada, Mineral Deposits Division Newsletter, 87, 1 and 4-9.

HEINRICH, C.A. (2005): The physical and chemical evolution of low-salinity magmatic fluids at the porphyry to epithermal transition: a thermodynamic study.- Mineralium Deposita, 39, 864-889. doi: 10.1007/s00126004-0461-9

HEINRICH, C.A. (2007): Fluid-fluid interactions in magmatic-hydrothermal ore formation.- Reviews in Mineralogy and Geochemistry, 65, 363-387. doi: $10.2138 / \mathrm{rmg} .2007 .65 .11$

HURTIG, N.C. \& WILLIAMS-JONES, A.E. (2015): Porphyry-epithermal Au-Ag-Mo ore formation by vapour-like fluids: New insights from geochemical modeling.- Geology, G36685-1.

JOLIVET, L. \& BRUN, J.P. (2010): Cenozoic geodynamic evolution of the Aegean.- International Journal of Earth Sciences, 99, 109-138. doi: 10.1007/s00531-008-0366-4

KESLER, S.E., BODNAR, R.J. \& MERNAGH, T.P. (2013): Role of fluid and melt inclusion studies in geologic research.- Geofluids, 13, 398-404. doi: 10.1111/gfl.12055

LANG, J.R. \& BAKER, T. (2001): Intrusion-related gold systems: the present level of understanding.- Mineralium Deposita, 36, 477-489. doi: 10.1007/ s001260100184

LEHMANN, B., DIETRICH, A. \& WALLIANOS, A. (2000): From rocks to ore.- International Journal of Earth Sciences, 89, 284-294. doi: 10.1007/ s005310000085

LOWENSTERN, J.B. (2001): Carbon dioxide in magmas and implications for hydrothermal systems.- Mineralium Deposita, 36, 490-502. doi: $10.1007 / \mathrm{s} 001260100185$

MARCHEV, P., KAISER-ROHRMEIER, M., HEINRICH, C., OVTCHAROVA, M., VON QUADT, A. \& RAICHEVA, R. (2005): Hydrothermal ore deposits related to post-orogenic extensional magmatism and core complex formation: the Rhodope Massif of Bulgaria and Greece.- Ore Geology Reviews, 27, 53-89. doi: 10.1016/j.oregeorev.2005.07.027

MELFOS, V. \& VOUDOURIS, P.C. (2012): Geological, mineralogical and geochemical aspects for critical and rare metals in Greece.- Minerals, 2, 300-317. doi: 10.3390/min2040300

MELFOS, V., CHATZIKIRKOU, A., MICHAILIDIS, K. \& VOUDOURIS, P. (2010): Fluids related to remobilization of Mesozoic sulfide mineralization in the Eptadendro-Rachi region in eastern Rhodope, Thrace, Greece.In CHRISTOFIDES et al. (eds.): Proceedings of the XIX Congress of the Carpathian-Balkan Geological Association, Thessaloniki. Scientific Annals of the School of Geology A.U.Th., 100, 343-350.

MELFOS, V., VAVELIDIS, M., CHRISTOFIDES, G. \& SEIDEL, E. (2002): Origin and evolution of the Tertiary Maronia porphyry copper-molybdenum deposit, Thrace, Greece.- Mineralium Deposita, 37, 648-668. doi: 10.1007/s00126-002-0277-4

MELFOS, V., VOUDOURIS, P., VAVELIDIS, M. \& SPRY, P. (2008): Microthermometric results and formation conditions of a new intrusion-related $\mathrm{Bi}-\mathrm{Te}-\mathrm{Pb}-\mathrm{Sb} \pm \mathrm{Au}$ deposit in the Kavala pluton, Greece.- In: Proceedings of the XIII All-Russian conference on thermobarogeochemistry in conjunction with IV APIFIS symposium, vol 2, 165-168.

NERANTZIS, N. (2009): Pillars of Power: Silver and Steel of the Ottoman Empire.- Mediterranean Archaeology and Archaeometry, 9, 71-85.

PE-PIPER, G. \& PIPER D.J. (2001): Late Cenozoic, post-collisional Aegean igneous rocks: $\mathrm{Nd}, \mathrm{Pb}$ and $\mathrm{Sr}$ isotopic constraints on petrogenetic and tectonic models.- Geological Magazine, 138, 653-668.

PE-PIPER, G. \& PIPER, D.J. (2002): The Igneous Rocks of Greece.- Gebroder Borntraeger, Berlin, Germany, 573 p. doi: 10.1017/ S0016756801005957

PERNICKA, E., GENTNER, W., WAGNER, G.A., VAVELIDIS, M. \& GALE, N.H. (1981): Ancient lead and silver production on Thasos (Greece).- Revue d'Archéométrie, 1, 227-237. doi: 10.3406/arsci.1981.1151

ROEDDER, E. (1977): Fluid inclusions as tools in mineral exploration.- Economic Geology, 72, 503-525. 
SIMMONS, S.F. \& BROWN, K.L. (2006): Gold in magmatic hydrothermal solutions and the rapid formation of a giant ore deposit.- Science, 314, 288-290. doi: 10.1126/science.1132866

TSIRAMBIDES, A. \& FILIPPIDIS, A. (2012): Exploration key to growing Greek industry.- Industrial Minerals, 533, 44- 47.

VAVELIDIS, M. \& AMSTUTZ, G.C. (1983): New genetic investigations on the $\mathrm{Pb}-\mathrm{Zn}$ deposits of Thasos (Greece).- In: SCHNEIDER, H.J. (ed.): Mineral Deposits of the Alpine Epoch in Europe, Berlin: Springer-Verlag, 359-365. doi: 10.1007/978-3-642-68988-8 36

VAVELIDIS, M. \& MELFOS, V. (2004): Bi-Ag-bearing tetrahedrite-tennantite in the Kapsalina copper mineralisation, Thasos island, Northern Greece.- Neues Jahrbuch für Mineralogie - Abhandlungen (Journal of Mineralogy and Geochemistry), 180, 149-169. doi: 10.1127/00777757/2004/0180-0149

VAVELIDIS, M., GIALOGLOU, G., MELFOS, V. \& WAGNER, G.A. (1996): Goldgrube in Palaea Kavala-Griechenland: Entdeckung von Skaptehyle?Erzmetall, 49, 547-554.

VAVELIDIS, M., GIAlOGloU, G., WAGNER, G.A. \& PERNICKA, E. (1988): Die Bundmetall- und Eisen-Mangan-Lagerstätten von Thasos.Anschnitt, 6, 40-58.

VAVELIDIS, M., SCHMIDT-MUMM, A. \& MELFOS, V. (1995): Microthermometric investigations in the $\mathrm{Bi}-\mathrm{Te}-\mathrm{Ag}$ bearing $\mathrm{Cu}$-mineralization of Panagia area, Thasos Island, Greece.- Boletin Soc. Espan. Mineralogia, 18-1, 261-262.

VAXEVANOPOULOS, M., VAVELIDIS, M., MALAMIDOU, D., MELFOS, V. \& PAVLIDIS, S. (in press): Excavations in ancient mines and metallurgical sites on the Pangaion mountain (Asimotrypes, Valtouda).- The Archaeological Work in Macedonia and Thrace (in press, in Greek)

VOUDOURIS, P. \& ALFIERIS, D. (2005): New porphyry $\mathrm{Cu} \pm \mathrm{Mo}$ occurrences in the north-eastern Aegean, Greece: Ore mineralogy and epithermal relationships.- In: MAO, J. \& BIERLEIN, F.P. (eds.): Mineral De- posit Research: Meeting the Global Challenge, Springer Berlin Heidelberg, 473-476.

VOUDOURIS, P. (2006): Comparative mineralogical study of Tertiary Te-rich epithermal and porphyry systems in northeastern Greece.- Mineralogy and Petrology, 87, 241-275.

VOUDOURIS, P., MELFOS, V., SPRY, P.G., BINDI, L., MORITZ, R., ORTELLI, M. \& KARTAL, T. (2013a): Extremely Re-rich molybdenite from porphyry $\mathrm{Cu}-\mathrm{Mo}-\mathrm{Au}$ prospects in northeastern Greece: Mode of occurrence causes of enrichment, and implications for gold exploration.- Minerals, 3, 165-191. doi: 10.3390/min3020165

VOUDOURIS, P., MELFOS, V., SPRY, P.G., KARTAL, T., SCHLEICHER, H., MORITZ, R. \& ORTELLI, M. (2013b): The Pagoni Rachi/Kirki Cu$\mathrm{Mo} \pm \mathrm{Re} \pm \mathrm{Au}$ deposit, Northern Greece: Mineralogical and fluid inclusion constrains on the evolution of a telescoped porphyry-epithermal system.Canadian Mineralogist, 51, 411-442.

VOUDOURIS, P., MELFOS, V., SPRY, P.G., MORITZ, R., PAPAVASSILIOU, C. \& FALALAKIS, G. (2011): Mineralogy and geochemical environment of formation of the Perama Hill high-sulfidation epithermal AuAg-Te-Se deposit, Petrota Graben, NE Greece.- Mineralogy and Petrology, 103, 79-100. doi: 10.1007/s00710-011-0160-z

VOUDOURIS, P.C., MELFOS, V., SPRY, P.G., BINDI, L., KARTAL, T. ARIKAS, K., MORITZ, R. \& ORTELLI, M. (2009): Rhenium-rich molybdenite and rheniite (ReS2) in the Pagoni Rachi-Kirki Mo-Cu-Te-AgAu deposit, Northern Greece: Implications for the rhenium geochemistry of porphyry style $\mathrm{Cu}-\mathrm{Mo}$ and Mo mineralization.- Canadian Mineralogist, 47, 1013-1036.

WILKINSON, J.J. (2001): Fluid inclusions in hydrothermal ore deposits.Lithos, 55, 229-272. doi: 10.1016/S0024-4937(00)00047-5

WILLIAMS-JONES, A.E. \& HEINRICH, C.A. (2005): 100th Anniversary special paper: vapour transport of metals and the formation of magmatichydrothermal ore deposits.- Economic Geology, 100, 1287-1312. doi: 10.2113/gsecongeo.100.7.1287 